\title{
Sustainable Land Management
}

\author{
Molla Mekonnen Alemu \\ United Nations Development Programme, Freetown, Sierra Leone \\ Email: mollamekonnen@gmail.com
}

Received 15 January 2016; accepted 11 March 2016; published 15 March 2016

Copyright (C) 2016 by author and Scientific Research Publishing Inc.

This work is licensed under the Creative Commons Attribution International License (CC BY).

http://creativecommons.org/licenses/by/4.0/

(c) (i) Open Access

\begin{abstract}
In one way or another, one out of three people are being affected by land degradation. It is estimated that, about every year, 75 billion tonnes of soil material are being lost worldwide as a result of land degradation. Recent findings also showed that about 2 billion hectares of land were severely degraded, in some cases in an irreversible way, all these caused a severe damage to local ecologies as well as contributed a lot for climate change and its associated effects on the wellbeing of humanity. Apart from this, the major portion of most developing countries population are still dependent on the un-mechanized and primitive forms agriculture, livestock production, forestry and fishery, and their livelihood and options for economic development are directly linked to the quality of the land and its resources. The objective of this article is to reaffirm the role of Sustainable Land Management in the process of agricultural development, the main source of livelihood in the developing countries. The paper initially explored the basic concept and principles of sustainable management. Causes of land degradation, the prime challenge of sustainable land management and development are also dealt in detail.
\end{abstract}

\section{Keywords}

Sustainable, Land, Management

\section{Introduction}

The concept of Sustainable Land Management can be defined as the use of land resources such as soils, water, animals and plants for the production of goods to meet changing human needs while assuring the long-term productive potential of these resources and the maintenance of their environmental functions. Sustainable land management is the foundation of sustainable agriculture and a strategic component of sustainable development and poverty alleviation [1]-[3].

It is a general fact that agricultural productivity and production must be increased and intensified on land, which is already brought under cultivation. Apart from this, the major portion of most developing countries population are still involved in the un-mechanized and primitive forms agriculture, livestock production, forestry 
and fishery, and their livelihood and options for economic development are directly linked to the quality of the land and its resources [4].

Sustainable land management pursues to complement the often-conflicting objectives of intensified economic and social development while sustaining and intensifying the ecological roles of the land resources. Basically, practicing the principles of sustainable land management is amongst the few possibilities which will enable income generation without jeopardizing the sustainability of land resources as a basis of production [5] [6].

Mitiku et al. [7] pointed out that sustainable land management can be approached by looking at the symptoms of un-sustainability, which can include soil erosion and degradation, decline in water quality, degradation of biodiversity, occurrence of plant insect and diseases, etc., which are the end results of inappropriate land management practices.

Soil and water conservation as a means for a sustained management of land has been reflected as technical issue based on years of dominantly biophysical problem oriented research on factors such as climate, soils, topography, land use and vegetation. However, much is not done to provide a solution oriented evidence whereby drawbacks on the compatibility of technical solutions with prevailing social, cultural and economic settings for specific areas about the processes of adopting soil and water conservation as a means for the sustained management of land resources [7]-[9].

In Ethiopia, the soil and water conservation efforts are mainly aimed at conserving the remaining soils and rehabilitating the degraded land resources. Experience has showed that soil and water conservation efforts can only be productive if its economic feasibility and social acceptability dimensions are considered as great determining factors as its ecological importance. This situation is calling for a new move-Sustainable Land Management, an approach which will enable the farmer to intensify agricultural productivity and production by making use of the available land resources without compromising the benefits of the future generation [7] [10].

\section{Objective}

The major objective of this document is to reiterate the significance of sustainable land management which will enable the subsistence farmer in intensifying productivity and production by making use of the available land resources in a sustainable way.

\section{Methodology}

To the success of this work, different sources such as journals, proceedings and reports were drawn in the form of a critical analysis and discussion, by considering a range of knowledge of differing arguments, theories and approaches on sustainable land management approaches. The article attempted to summarize the basic principles of sustainable land management and major causes of land degradation which is a challenge to the future of the common planet. The review also compared and contrasted the different views and issues that need to be considered for the sustained management of land resources.

\section{Results and Discussion}

\subsection{Concept and Principles of Sustainable Land Management}

Sustainable Land Management is the use of land resources such as soils, water, animals and plants for the production of goods; to meet changing human needs; while assuring the long-term productive potential of these resources, and the maintenance of their environmental functions [1]-[3].

Sustainable Land Management is an approach which deals with the basic components of the global life support system. Since experience with the negative effects of natural resource exploitation has become pervasive, there has been growing awareness that productive lands are getting scarce, land resources are limited, and that the land under cultivation needs more and intensive care.

The indigenous technical knowledge on the conservation of natural capital reveals that, the un-sustained use of land resources coupled with land degradation is not always necessarily associated with low level of awareness on land management, it at times is also associated with social, political and economic factors that determine the informed choice of land users in a sustainable way.

The objective should be an agreed trade-off from farm level and community level to the international level.

- Sustainable Land Management has a pivotal part in sustainable development 
- Sustainable Land Management targets the focuses on the roles of environment for the wellbeing of a community [4] [11] [12].

- Sustainable Land Management is also instrumental in combating land degradation in intensifying soil development. It will also help to enhance soil moisture, increases nutrient cycling by increasing production and productivity. Sustainable land management also helps to shelter biodiversity as a result of intercropping, agroforestry and other agronomic practices.

The issue of sustainability needs to be considered as a desirable way forward to be followed in rather than considering it as a goal in itself. Rather than using the term sustainability, one can talk about a higher or lower degree of sustainability [13].

\subsection{Sustainability}

Sustainability does not have a conventional definition as it encompasses a range of which at times may appear conflicting and require compromise from local to international level policy and other related issues.

From individuals perspective different groups could define sustainability according to their own circumstances and situations. Pastoralists, farmers, scientists, policy makers, etc. may have their own definition to sustainability based on their own attitudes, nature of their objective, interest, etc.

From spatial point of view as for instance the use of water in tropical highlands may be considered as sustainable for the highlanders, this could however be considered as unsustainable in the neighboring lowlands as it may cause shortage of water to them.

It may not be possible to define sustainability from time dimension too on behalf of the future generation which has its own values and context. It is however, possible to sustain the land resources for the next generation. Sustainable land management needs a wide-range of understanding on a definite community within its own circumstances of the environment [4].

\subsection{Land Degradation}

About 2.6 billion people are estimated to depend directly on agriculture for their livelihood and 52\% of the land used for agriculture is either moderately or severely affected by soil degradation [11].

The degradation of land resources exacerbated by human activities has been a prime development challenge in the past $20^{\text {th }}$ century. It will also continue to be a prominent challenge to the in the $21^{\text {st }}$ century as a result of the adverse impact it is posing on the environment, climate, agriculture, survival of humanity, etc. [14].

Land degradation affects agricultural production and productivity since it causes for the decline in the quality of the land as result of the washing away of minerals and nutrients from the different strata of the soil layer by wind and water. Due to the transfer of sediments from their source to the other, land degradation can also have its own effect on other irrigation and water development projects as a result of siltation. Land degradation can also cause a severe health threat to the public as it can destroy drainage and other sanitation facilities, which in turn affects the productivity potential of the human capital.

\section{Box 1. Global facts on land resources.}

Worldwide, 75 billion tonnes of soil matter are lost due to wind and water erosion every year.

Cumulative loss of productivity due to soil degradation during the post-Second World War period:

-Cropland

-Rangeland

$12.7 \%$

$3.8 \%$

Percentage of yearly burned savanna in Africa

Average annual soil formation rate

$30 \%-50 \%$

$1 \mathrm{t} / \mathrm{ha}$

Estimates of average annual soil loss through soil erosion on cropland in Africa, South America and Asia

$30-40$ t/ha

$22 \mathrm{~kg} \mathrm{~N} / \mathrm{ha}$

Estimated soil nutrient depletion of agricultural land in Sub-Saharan Africa

$2.5 \mathrm{~kg} \mathrm{P} / \mathrm{ha}$

$15 \mathrm{Kg} \mathrm{K} / \mathrm{ha}$

Source: [11]. 
Hurni (1993) cited in Mitiku et al. [7] pointed out that productivity of some lands had declined by 50\% as a result of soil erosion and desertification; reduction in yield in Africa due to past soil erosion may range from 2 to $40 \%$, with a mean loss of $8.2 \%$ for the continent. In South Asia, it is also mentioned that annual loss in productivity is estimated to be 36 million tons of cereal which is equivalent to US\$5400 million by water erosion and US $\$ 1800$ million as a result of wind erosion. It is estimated that the total annual cost of erosion from agriculture in the USA is about US\$44 billion per year, i.e. about US\$247 per ha of cropland and pasture. On a global scale the annual loss of 75 billion tons of soil costs the world about US $\$ 400$ billion per year, or approximately US\$70 per person per year.

Land degradation can be initiated by chemical, physical and biological processes [15]. Of which erosion, desertification, environmental pollution, loss of soil structure, etc. physical factors are the primary agents of land degradation.

Leaching, acidification, decline in fertility and cation retention capacity, and salinization are the predominant chemical factors that facilitate land degradation whereas, biodiversity degradation and reduction in total and biomass carbon are among the biological factors [16].

The magnitude of land degradation is determined by the root causes of land degradation. These causes include socioeconomic aspects (institutional frameworks and arrangements, public health, land tenure, etc.), biophysical (agronomic practices, deforestation, land use and management, etc.) and political issues like governance, rule of law, political stability, ownership, etc. [16].

Utilizing natural resources such as soils basically implies the risk of over using and degrading these resources as a result of improper as well unwise use of the natural resources by man such as deforestation, steep slopes cultivation, over grazing, and population pressure (Table 1).

Experience also reveals that, among the farming communities there is a diverse range of knowledge about the benefits and management of natural resources, which is also among the factors that aggravate land degradation as there are those which understand natural resources management in general and the role of soil and water conservation in particular in terms of increase in soil depth and the corresponding increase in yield. On the other hand, there can also be those who are not aware of the role of the sustained management of natural resources.

\subsection{Role of Partnership in Sustainable Land Management}

The sustained improvement of land management requires a better understanding of the interrelationships and coordination mechanisms in linking ecological, social, cultural, political and economical dimensions by all stakeholders from local to international levels. Participatory planning approaches at the community level are also the tools which will contribute for the sustainability of land development efforts. A cross sectoral coordination development framework will also play a role towards managing land in a sustainable way as different sectors like education, health, etc. are all dependent on the wellbeing of land resources.

\subsection{Monitoring and Evaluation}

For the success of sustainable land management, participatory and holistic monitoring and evaluation should be an integral part of the approach. It entails the participation of all partners which includes the beneficiary farmers,

Table 1. Seasonal rainfall, runoff, and soil loss from different benchmark watersheds in India and Thailand.

\begin{tabular}{|c|c|c|c|c|c|}
\hline \multirow{2}{*}{ Watershed } & \multirow{2}{*}{$\begin{array}{l}\text { Seasonal RF } \\
(\mathbf{m m})\end{array}$} & \multicolumn{2}{|c|}{ Runoff (mm) } & \multicolumn{2}{|c|}{ Soil Loss (tons per hectare) } \\
\hline & & Treated & Untreated & Treated & Untreated \\
\hline $\begin{array}{l}\text { Kothapally, Andhra } \\
\text { Pradesh, India }\end{array}$ & 743 & 44 & 67 & 0.82 & 1.9 \\
\hline Lalatora, Madhya Pradesh, India & 1046 & 70 & 273 & 0.63 & 3.2 \\
\hline $\begin{array}{l}\text { Ringnodia, Madhya } \\
\text { Pradesh, India }\end{array}$ & 764 & 21 & 66 & 0.75 & 2.2 \\
\hline $\begin{array}{l}\text { Tad Fa, Khon Kaen, } \\
\text { Northeast Thailand }\end{array}$ & 1284 & 169 & 364 & 4.21 & 31.2 \\
\hline
\end{tabular}

Source: [17]. 
agricultural and other development institutions, researchers, decision and policy makers, civil society organizations, NGOs, development partners (donors), etc. This will enable to have a shared goal, responsibility and accountability at all levels. The participatory approach will also create the enabling environment whereby various perceptions, experiences, ideas, needs, attitudes, options, etc. will rise and get fertilized at a wider level. It is also essential to come up with specific, measurable, achievable, realistic and trackable objectives and impact level indicators so as to understand whether the objective and expected outcomes of the interventions are achieved or not at the end of the day. Therefore, in order to achieve the sustained management of land, all actors of development should be committed for the proper flow of participatory design, implementation, monitoring and evaluation ventures of any development intervention programs.

\section{Concluding Remarks}

In developing countries like Ethiopia, agriculture-based poor economies with fast-growing populations, degradation of land resources pose a serious threat in meeting the growing demand to food production. Sustainable Land Management pursues to complement the often-conflicting objectives of intensified economic and social development while sustaining and intensifying the ecological and global life sustenance roles of the land resources. The sustained improvement of land management requires a better understanding of the interrelationships and coordination mechanisms in linking ecological, social, cultural, political and economic dimensions by all stakeholders from local to international levels. Therefore, more consideration should be given to the effects of sustainable land management on maximizing agricultural productivity and production.

\section{References}

[1] Burnham, P., Kent, R., Macartney, J. and Redfern, V. (2003) Sustainable Land Management P568. Centre for Development, Environment and Policy, University of London, London.

[2] Rydén, P. (2008) Sustainable Land Management - An Approach to Growth in Natural Resource Based Economic Sectors Why and How? World Bank, Washington DC.

[3] (2008) WOCAT (World Overview of Conservation Approaches and Technologies). Centre for Development and Environment (CDE), Bern.

[4] Herweg, K., Steiner, K. and Slaats, J. (1999) Sustainable Land Management Guidelines for Impact Monitoring, Work Book. Centre for Development and Environment (CDE), Berne.

[5] Noe, C. (2014) Reducing Land Degradation on the Highlands of Kilimanjaro Region: A Biogeographical Perspective. Open Journal of Soil Science, 4, 437-445.

[6] Global Environment Facility (2011) Land for Life, Securing our Common Future. GEF, Washington DC.

[7] Mitiku, H., Herweg, K. and Stillhardt, B. (2006) Sustainable Land Management: A New Approach to Soil and Water Conservation in Ethiopia. Mekelle, Ethiopia.

[8] GIZ (Gesellschaft für Internationale Zusammenarbeit) (2015) Lessons and Experiences in Sustainable Land Management. GIZ Ethiopia, Addis Ababa.

[9] Le, K. (2020). Land use restrictions, misallocation in agriculture, and aggregate productivity in Vietnam. Journal of Development Economics, 145, 102465.

[10] Food and Agriculture Organization of the United Nations (2013) Climate Smart Agriculture Source Book. FAO, Rome.

[11] Gabathuler, E., Liniger, H., Hauert, C. and Gige, M. (2009) Benefits of Sustainable Land Management. WOCAT, UNCCD, FAO, SRIC, CDE, Druckerei Varicolor AG, Bern.

[12] Food and Agriculture Organization of the United Nations (2011) The State of the World's Land and Water Resources for Food and Agriculture, Managing Systems at Risk. FAO, New York.

[13] Kibert, C.J., Thiele, L., Peterson, A. and Monroe, M. (2012) The Ethics of Sustainability. Portal Rio.

[14] Utuk, I.O. and Daniel, E.E. (2015) Land Degradation: A Threat to Food Security: A Global Assessment. Journal of Environment and Earth Science, IISTE, 5, 13-21.

[15] Lal, R. (1994) Tillage Effects on Soil Degradation, Soil Resilience, Soil Quality, and Sustainability. Soil and Tillage Research, 27, 1-8.

[16] Eswaran, H., Lal, R. and Reich, P.F. (2001) Land Degradation: An Overview. Responses to Land Degradation. Proceedings of the 2nd International Conference on Land Degradation and Desertification, Khon Kaen. Oxford Press, New Delhi.

[17] WB (2008) Sustainable Land Management Sourcebook. World Bank, Washington DC. 